to which there seemed every human probability he might reach. At an early age he turned his attention to scientific pursuits, and commenced his career as a chemist, the training for which so eminently fitte 3 him for the active part he took for the last twenty-five years in matters relating to photography. When scarcely o: age he wrote his "Traité Générale de Photographie," a new edition of which was called for almost year by year, its popularity being nearly unprecedented. Usually sound in his ideas, we may take it that much of the teaching of photochemistry has been propagated through the instrumentality of that work. Not only was Van Monckhoven an ardent experimentalist in the domain of chemical physics, but he also entered into all optical questions bearing on photography with a zeal which those alone who had the pleasure of his acquaintance can estimate. The Monckhoven solar enlarging apparatus is a standing record of his great ability in this department of science. At a very early period of his career he applied the spectroscope to record the effects of light on different inorganic and organic bodies, and his photographic researches on the spectra of gases occupied no inconsiderable portion of his time; his very latest published work, presented recently to the Académie des Sciences, being on the effect of temperature and pressure on hydrogen. Whilst Science, for herself, had charms for Van Monckhoven, yet he was able to put to commercial use much of the knowledge which he had acquired. For instance, he entered with enthusiasm into the mysteries of carbon printing, and established a factory for the production of the necessary tissue. Indeed the Monckhoven's tissue is the only one which enters into any sort of competition with that manufactured by the Autotype Company. Again to perfect the preparation of the latest photographic novelty-gelatine plates-he rushed into researches with all the ardour of an experimentalist, and having more or less mastered its intricacy, he established a manufactory for their commercial issue, and probably the Monckhoven plates are better known on the Continent than any other. Van Monckhoven, besides being the author of the treatise on photography, contributed many memoirs to various periodicals, amongst which we may name $L a$ Lumière, Le Bulletin Belge, and La Revue des deux Mondes. His style was vigorous, and everything he had to say was written with a terseness which many a busy scientific man may envy. In reviewing Van Monckhoven's life we cannot point to any great discovery or to any startling inventions he made, but he was one of those men who are so useful to science, giving, as it were, the decorations to the more solid building. We are sure that thougb there may be greater names, there is scarcely one which is more universally known than his, and whose loss will be more universally felt. There are not many who can claim to be dictinguished as an astronomer, a chemist, an optician, and photo-chemist, Van Monckhoven could make good his claim to such distinction, and withal to be a busy man in the world of commerce.

Within a short time of his death he was engaged in an important research on the influence of pressure and temperature on the spectra of gases, in which he had introduced quite a new method of attack, and one which promised to be of great value.

\section{THE CHEMISTRY OF THE PLANTE AND FAURE ACCUMULATORS}

\section{PART IV.-The Function of Sulphate of Lead}

I $N$ our previous communications on the chemistry of the lead and peroxide batteries we have frequently remarked on the formation of lead sulphate and its importance in the history of a cell.

in Part I. (Nature, vol. xxy. p. 221) we showed that the local action that takes place at first energetically between the metallic lead and the peroxide is gradually diminished by the formation of sulphate of lead.

In Part II. (vol. xxv, p. 46I) we stated that in the original formation of a Faure cell sulphate of lead is oxidated on the one plate and reduced on the other. We also described an experiment in which two platinum plates were covered with lead-sulphate, immersed in dilute sulphuric acid, and placed in the circuit of a galvanic current; the result being that "the white sulphate was decomposed to a large extent on each plate, the positive being covered with deep chocolate-coloured peroxide, the negative with grey spongy lead."

In Part III. (vol. xxvi. p 25I) we showed that on the discharge of a cell, lead sulphate is the ultimate product on both plates.

It might naturally be inferred from our previous statements that in the re-charging of a cell this lead sulphate would be oxidated on the one plate and reduced on the other as in the original formation. This matter, however, has given rise to so.ne controversy. All subsequent experimenters admit the oxidatzon of the lead-sulphate, but Dr. Oliver Lodge could not obtain any reduction of it, when pure sulphate was employed. Sir William Thomson also, when experimenting, with two platinum plates and layers of sulphate, obtained only a doubtful indication of reduced metal. The question as to whethes the sulphate is reduced or not on re-charging a Faure cell is one of vital importance; for if the sulphate formed at each discharge accumulates on the positive plate it would clog up the space, and, what is perhaps worse, a fresh surface of the lead would have to be oxidated (or rather, converted into sulphate) at each dis sharge. Thus the positive plate will be continually corroded, and its life will be limited.

We have already replied to Dr. Lodge in NATURE (vol. xxvi. p. 342), but we thought it desirable to repeat the experiment with the platinum plates, especially with a view to determine whether the reduction was effected slowly or with any rapidity. We fastened 20 grms. of the white sulphate upon a negative plate by binding it round tightly with parchment-paper, placed it vertically in the sulphuric acid, and passed a continuous current of somewhat under an Ampère. The hydrogen was at no time wholly absorbed-indeed the greater part of it certainly escaped--but after the lapse of twenty-four hours, small patches of grey metallic lead became distinctly visible through the wet parchment-paper; and these gradually spread in an irregulur manner. At the end of ten days it was found that the whole of the sulphate, except a few small patches on the surface, was reduced to a grey spongy mass. Although there could be no reasonable doubt that this was metallic lead, a portion of it was tested caemically, and proved to be such.

It thus appears that the reduction of the pure sulphate: of lead is an absolute fact, although it does not take place so easily as the oxidation.

In an actual cell the sulphate of lead is of course mixed with other bodies. Thus, in the formation of a Faure battery, the minium is converted by the sulphuric acid more or less completely into peroxide of lead and sulphate. We have already described an experiment in which 4489 c.c. of hydrogen were absorbed on a plate, the materials of which were capable of absorbing only 4574 c.c., if the whole sulphate as well as the peroxide was reduced In our note-book we have the particulars of four other experiments made in each case with the same, or nearly the same, amount of material, in which 4199, 4575,4216 , and 4387 c.c. respectively were absorbed, although perhaps in not one of these cases was the experiment continued until the action was absolutely complete. As, however, it may be objected that the amount of sulphate produced upon these plates was an unknown quantity, we have in a recent experiment treated the 
minium in the first instance with a considerable amount of sulphuric acid. This gave us a mixture which, on analysis, was found to contain 18.5 per cent. of sulphate of lead. This mixture, when submitted to the reducing action of a current yielded a mass of spongy lead that contained only a mere trace of sulphate.

As it seemed desirable fuily to establish the fact that the sulphate of lead formed on the discharge of a cell is reduced in the subsequent charging, we took the quondam lead plate of a fully discharged cell, determined the proportion of sulphate to unaltered spongy lead, and submitted it to the reducing action of a current. The amount of sulphate on the plate before passing the current was found to be $5 \mathrm{I}$ per cent., but, after the passage of a current, of about an ampère for 60 hours, not a trace of it remained.

Hence it may be concluded that, during the alternate discharging and re-charging of a Planté or Faure cell, sulphate of lead is alternately formed and reduced on the lead plate, and that the plate itself is not seriously corroded. It would, however, appear desirable not to allow the whole of the spongy lead to be reduced to sulphate during the discharge, for two reasons, viz. : (I) because the supporting plate stands a chance of being itself acted on if there is not a sufficient excess of spongy metal; and (2) because the presence of this excess tends to facilitate the reduction of the sulphate.

We have already shown that sulphate of Jead is produced by the local action that takes place between the peroxide and its supporting lead plate during repose. The same local action also takes place during the charging of the plate, as was pointed out in our second communication, and this sulphate is, in its turn, attacked by the electrolytic oxygen. In this way the absorption of oxygen in forming the negative plate ought never to come to an end. In order to see whether this was the case, we allowed an experiment to continue for I I 5 hours, although the main action was over in about forty hours. For the last two days of the experiment, the amount of oxygen absorbed was pretty constant, being about 9 c.c. per hour, which is equivalent to 0.24 grms. of sulphate of lead formed and oxidated. The whole charge on the plate was forty grms. of peroxide. This local action also takes place during the discharge, as is evidenced by the sulphate of lead formed on the negative plate always exceeding in amount that formed on the positive plate.

Through this local action taking place during the formation of the cell, during repose, and during the discharge, the lead plate which supports the peroxide must be continually corroded more and more; and it is probably due to the insolubility of the sulphate formed that the destruction of this kind of secondary battery is so materially retarded in practice.

\section{J. H. GLADSTONE} ALFRED TRIBE

\section{REFLECTIONS ON READING "DEGENERA-} TION": AN ESSAY, BY E. R. L., F.R.S.

$T H E$ Ascidian came down like a wolf on the fold

1 In the ages ere Earth had grown wrinkled and old, He peered through the waves with his cerebral eye, Frisked his tail, and dashed after the innocent fry.

Like the leaves of the forest when Summer is green That gay host of youthful Ascidians was seen, Like the leaves of the forest when Autumn has blown Their helpless descendants lie glued to a stone.

For the Angel of Darwin came, gentle and bland, And lapped them in comfort and fed them by hand, And their eye myelonic waxed useless and blind, And their caudal appendage was cut off behind.
And there lies the sea-squirt with gill-slits all wide And through them there eddies the nutritive tide, Half mollusc, half vertebrate, solve him who can, A riddle, a lesson for curious Man.

\section{J. H, P.}

ILLUSTRATIONS OF NEW OR RARE ANIMALS IN THE ZOOLOGICAL SOCIETY'S LIVING COLLECTION

\section{IX.}

23. THE PIGMY HOG (Porcula salvania).-Few additions to the Zoological Society's living collection of late years have attracted more attention than the Pigmy Hogs of Nepaul, of which the first specimens ever imported into Europe reached the Gardens in May last.

For our first knowledge of the existence of this diminutive form of the pig-family in the sub-Himalayan forests we are indebted to the researches of Mr. Bryan $\mathrm{H}$. Hodgson, formerly Resident at the Court of Nepaul, who described the Pigmy $\mathrm{Hog}$ so long ago as 1847, in an article published in the Journal of the Asiatic Society of Bengal. He named it Porcula salvania, from the forest of Saul trees (Shorea robusta), in which it is chiefly found. While the Wild Boar, or a species closely resembling it abounds all over India, the Pigmy Hog is exclusively confined, as Mr. Hodgson tells us, to the deep recesses of the primeval forests of the Terai of Nepaul and Bhotan, where it roams about in herds. It is very rarely seen even by the natives. A well-known hunter informed Mr. Hodgson that during fifty years' abode in the Saul forests he had obtained but three or four of these animals to eat, partly owing to their scarcity, and partly to the speed with which the females and young disperse, and to the extraordinary vigour and activity with which the males defend themselves while their families are retreating. Dr. Jerdon in his volume on the Mammals of India, tells us that the full grown males live constantly with the herd, which consists from five to twenty indi. viduals, and are its habitual and resolute defenders against harm. These animals feed principally upon roots and bulbs, but also devour birds' nests, eggs, insects, and reptiles. The female has a litter of from three to four young ones. Dr. Jerdon adds, that whilst at Darjeeling, he in vain endeavoured to procure a specimen of it from the Sikkim Terai, and Sir Joseph Fayrer, who hunted many years in the Terai, was also unsuccessful in meeting with the Pigmy Hog.

Under these circumstances, it will be readily understood that the authorities of the Society have been much pleased at the recent acquisition of a small herd of these animals, consisting of a male and three females, of cne of which we give an illustration (Fig. 23). They were obtained in the Western Dooars of Bhootan after vast trouble and expense, and were brought to England by Mr. B. H. Carew, who has parted with them to the Society. They were caught by Mr. Carew's hunters in snares which were set for them in hundreds, over a range of country twenty miles in extent. Though on their first arrival they were very wild, they are already becoming tame and confidential, and are, it is hoped, likely to breed.

In its general appearance the Pigmy $\mathrm{Hog}$ is not unlike a small variety of the common boar, but measures only about I foot 2 inches in lengtb, and has but a very small tail. The colour is a nearly uniform brown, slightly shaded with dirty amber. The coat of hair is thin, except upon the back. The Pigmy Hogs will be found by visitors to the Zoological Society's Gardens in what is usually called the Ostrich House, just beyond the Zebra House, where a compartment has been specially fitted up for their accommodation.

\footnotetext{
I Continued from r. $\mathrm{r} 34$.
} 